\title{
Editorial
}

A pesquisadora Maria Malta Campos, da PUC-SP e da Fundação Carlos Chagas, nossa entrevistada da edição, é uma observadora atenta do cenário da Educação Infantil no país e, especialmente, de suas especificidades. Por isso, se preocupa muito com a qualidade dos serviços e da educação ofertados por creches e pré-escolas. Ao iniciar bebês e crianças pequenas em um processo de socialização não mais intermediado pela família, além de articular os saberes e as experiências que já trazem aos conhecimentos que fazem parte do patrimônio cultural, artístico, científico e tecnológico da humanidade, essa etapa da Educação Básica revela-se decisiva para a trajetória de vida de qualquer indivíduo. Desde que haja, à frente daquele pequeno grupo de crianças, um profissional bem formado. $E$ aqui começam os problemas que parecem se espraiar por todas as demais etapas da educação no país. Dentre eles, um dos mais agudos é a formação docente.

Para nossa entrevistada, o modelo atual de formação de professores no Brasil precisaria ser reformulado "porque não satisfaz nem o professor de Educação Infantil, nem o dos primeiros anos do Ensino Fundamental". Isso porque, explica a pesquisadora, quando foram elaboradas as Diretrizes Curriculares para os cursos de pedagogia e licenciaturas, optou-se por um caminho generalista, no qual todos recebem a mesma formação, seja para trabalhar com bebês ou crianças pequenas, na Educação Infantil ou no Ensino Fundamental, com educação inclusiva ou indígena. "Ou seja, a pessoa precisaria ser um gênio!", comenta Maria Malta na entrevista. Para ela, o que mais funciona é a formação continuada e em contexto: "Não é uma aulinha, nem uma palestra, uma conferência, uma semana de formação de vez em quando, mas é aquela formação que se faz no dia a dia, embebida naquele fazer cotidiano; mas para isso a pessoa precisa estar lá o tempo todo".

Além da participação de uma das mais reconhecidas especialistas no tema em atividade no país, esta edição traz 
um dossiê sobre Educação Infantil composto por seis artigos, todos oriundos de dois grupos de pesquisa orientados por nossa entrevistada no Programa de Pós-Graduação em Educação: Currículo da Pontifícia Universidade Católica de São Paulo (PUC-SP). Intitulado "Estudos sobre currículo, formação de professores e gestão na Educação Infantil em pesquisas orientadas por Maria Machado Malta Campos", os artigos que compõem esse dossiê serão apresentados por suas organizadoras, Marisa Vasconcelos Ferreira e Beatriz Abuchaim, após a entrevista, com a qual, aliás, estabelecem um diálogo vivo. Em comum a todos os artigos do dossiê, o fato de serem trabalhos sobre Educação Infantil, sob a perspectiva do currículo, e terem tido a mesma orientadora.

Durante o processo de leitura dos artigos presentes no dossiê pelo corpo de pareceristas de Veras recebemos duas contribuições que não integram o conjunto originalmente enfeixado e apresentado pelas organizadoras do dossiê, mas não deixam de contemplar aspectos relevantes da Educação Infantil - e, curiosamente, tendo como pano de fundo a análise do currículo. Por isso, esses artigos também foram selecionados para integrar esta edição.

Em Avaliação: Para que te quero? Um olhar voltado para além do educar e cuidar, Aline Dias Nascimento e Rita Oliveira André analisam o impacto de uma autoavaliação no município de São Paulo, citada na entrevista, que envolveu, além de professores e direção, o corpo de funcionários e as famílias das crianças. As autoras analisam uma dimensão específica das nove que integraram a versão final dos Indicadores de Qualidade da Educação Infantil Paulistana, a "Participação, escuta e autoria de bebês e crianças". Para elas, ao invocar a colaboração das famílias, a autoavaliação potencializou a creche como um espaço no qual os adultos aprendem entre si. Nesse cenário, observam, "os adultos que respondem às perguntas dos indicadores com comentários sobre as suas próprias percepções proporcionam a outros pais, mesmo desconhecendo a rotina, a possibilidade de conhecerem e terem vontade de entender melhor a unidade".

A discussão envolvendo o texto proposto pela Base Nacional Comum Curricular para a Educação Infantil, igualmente abordada na entrevista desta edição, é o tema de análise de Thais Monteiro Ciardella em seu artigo Pequenos e 
bem pequenos no centro das discussões curriculares: as Diretrizes Curriculares Nacionais para a Educação Infantil e seus desdobramentos. Após apresentar um mapeamento da produção e do contexto em que se deu a publicação das Diretrizes Curriculares Nacionais para a Educação Infantil, de 1999, e de sua revisão, em 2009, a autora avalia as discussões sobre um currículo na Educação Infantil organizado em "campos de experiência", tal como está proposto na Base Nacional Comum Curricular.

Completam esta edição, densa e com artigos de fôlego, duas colaborações que abordam outros aspectos da educação. Em Discursos fora do lugar: uma análise sobre atividades com rótulos na alfabetização, Ercilene Vita analisa um determinado tipo de atividade de alfabetização, a leitura de rótulos, proposta nos Parâmetros Curriculares Nacionais, tal como ela é apresentada em alguns sites que oferecem a professores material didático de caráter exploratório. E conclui que, na maioria dos casos, a atividade com rótulos de embalagens pode ser confundida com um exercício que tem mais o caráter de estimulante do consumo, ao exibir marcas e produtos com ênfase exagerada, do que o caráter educativo pretendido.

A contribuição de Daniel de Brito Júnior, Progressão continuada e interdisciplinaridade, após mostrar como esses dois conceitos se interpenetram, avança para apontar a necessidade de a interdisciplinaridade estar mais presente na formação do profissional que irá atuar no Ensino Fundamental, especialmente nas redes que adotam a progressão continuada. Estas, no entendimento do autor, precisam rever seus currículos de modo a torná-los cada vez mais interdisciplinares, ressaltando a importância de se discutirem as diferentes dimensões do currículo, para além do que ele já foi enfocado nos artigos presentes no Dossiê Educação Infantil.

\section{Boa leitura!}

Lucilia Bechara Sanchez, diretora pedagógica do Instituto Vera Cruz Ricardo Prado e Lisandra Ogg Gomes, editores da revista Veras

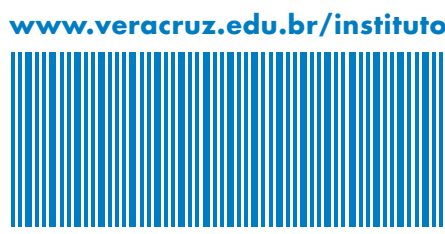

